MT study. The sediments beneath Sanchore, Patan and Mehsana sub-basins are much thicker and comparatively less thicker over Diyodar and Tharad ridges. The resistive blocks on the western margin of CRB represent igneous intrusives whereas on eastern margin, they indicate the Precambrian formations of the Aravalli-Delhi fold belt. The electrical resistivity variations across these basins infer that the subsurface structure is highly heterogeneous in nature, due to the faults within the rift basins. Thus the results of our MT study together with other geophysical studies and well data, may further refine the sediment thickness estimates across the rift basins.

1. Chave, A. D. and Jones, A. G., The Magnetotelluric Method: Theory and Practice, Cambridge University Press, 2012.

2. Biswas, S. K., Rift basins in the western margin of India and their hydrocarbon prospects. Bull. Am. Assoc. Pet. Geol., 1982, 66, $1497-1513$

3. Biswas, S. K., Regional tectonic framework, structure and evolution of the western marginal basins of India. Tectonophysics, 1987, 135, 307-327.

4. Kaila, K. L., Tewari, H. C., Krishna, V. G., Dixit, M. M., Sarkar, D. and Reddy, M. S., Deep seismic sounding studies in the north Cambay and Sanchore basins, India. Geophys. J. Int., 1990, 103 621-637.

5. Mishra, D. C., Gupta, S. B. and Tiwari, V. M., A geotransect from Dharimanna to Billimora across the Cambay and Narmada-Tapti rift basins, India. Int. Geol. Rev., 1998, 40, 1007-1020.

6. Kumar, G. P., Mahesh, P., Nagar, M., Mahender, E., Kumar, V., Mohan, K. and Kumar, M. R., Role of deep crustal fluids in the genesis of intraplate earthquakes in the Kachchh region, northwestern India. Geophys. Res. Lett., 2017, 44, 4054-4063.

7. Danda, N., Rao, C. K. and Kumar, A., Geoelectric structure of northern Cambay rift basin from magnetotelluric data. Earth Planets Space, 2017, 69, 140.

8. Biswas, S. K., A review on the evolution of rift basins in India during the Gondwana with special reference to western Indian basins and their hydrocarbon prospects. PINSA, 1999, 65, 261283.

9. Jones, A. G. and Jödicke, H., Magnetotelluric transfer function estimation improvement by a coherence-based rejection technique. Paper presented at 54th Annual Meeting, Society of Exploration Geophysicists, Atlanta, USA, 1984.

10. Jones, A. G., Chave, A. D., Egbert, G., Auld, D. and Bahr, K., A comparison of techniques for magnetotelluric response function estimation. J. Geophys. Res., 1989, 94, 14201-14213.

11. McNeice, G. W. and Jones, A. G., Multisite, multifrequency tensor decomposition of magnetotelluric data. Geophysics, 2001, 66, 158-173.

12. Spratt, J. E. and Craven, J., Magnetotelluric imaging of the Nechako basin, British Columbia, Canada. Geological Survey of Canada, Current Research, 2010, 2010-3.

13. Rodi, W. and Mackie, R. L., Nonlinear conjugate gradients algorithm for 2-D magnetotelluric inversion. Geophysics, 2001, 66, 174-187.

14. Ogawa, Y., On two dimensional modeling of magnetotelluric field data. Surv. Geophys., 2002, 23, 251-273.

15. Rao, C. K., Ogawa, Y., Gokarn, S. G. and Gupta, G., Electromagnetic imaging of magma across the Narmada-Son lineament, central India. Earth Planets Space, 2004, 56, 229-238.

16. Bera, P. and Rao, C. K., Magnetotelluric method: a tool for deep crustal study. In 9th Biennial International Conference and Exposition on Petroleum Geophysics, Mumbai, Society of Petroleum Geophysicists, India, 2012, pp. P-068.
17. Seshu, D., Rama Rao, P. and Naganjaneyulu, K., Threedimensional gravity modeling of Kutch region, India. J. Asian Earth Sci., 2015, 115, 16-28.

18. Chandrasekhar, D. V. and Mishra, D. C., Some geodynamic aspects of Kutch basin and seismicity: an insight from gravity studies. Curr. Sci., 2002, 83, 492-498.

19. Rao, V. V., Prasad, B. R., Reddy, P. R. and Tewari, H. C., Evolution of Proterozoic Aravalli-Delhi Fold Belt in the northwestern Indian Shield from seismic studies. Tectonophysics, 2000, 327, 109-130.

ACKNOWLEDGMENTS. We are grateful to IIG MT group members, Amit Kumar, P. B. V. Subba Rao, V. Purushottam Rao and A. K. Singh; Pavan Kumar, ISR, Gujarat; B. I. Panchal, IIG; Santanu Banerjee and E. Chandrasekhar, IIT Bombay; Max Moorkamp, LudwigMaximilians-University (LMU), Germany for all the support and suggestions. N.D. is thankful to DST, Govt of India for Ph D fellowship. C.K.R. acknowledges the funds by MoES, Govt of India, through the project (MOES/P.O (Seismo)/1(130)/2011).

Received 13 April 2018; revised accepted 8 October 2018

doi: $10.18520 / \mathrm{cs} / \mathrm{v} 116 / \mathrm{i} 2 / 299-304$

\section{Retreating rate of Chaturangi glacier, Garhwal Himalaya, India derived from kinematic GPS survey and satellite data}

\section{Harish Bisht ${ }^{1, *}$, Meenu Rani ${ }^{1}$, Kireet Kumar ${ }^{1}$, Saurabh Sah ${ }^{1}$ and Prakash Chandra Arya ${ }^{2}$}

${ }^{1}$ G.B. Pant National Institute of Himalayan Environment and Sustainable Development, Kosi-Katarmal, Almora 263 643, India ${ }^{2}$ Centre of Earth Sciences, Indian Institute of Science,

Bengaluru 560 012, India

The regular monitoring of glaciers is important to determine their retreating rate and mass balance for overall glacier health. Chaturangi glacier, a major inactive tributary of the Gangotri glacier system was selected for the present study due to its dynamic nature and also because there are no previous records of its retreating rates. In order to reconstruct past retreating rates, total area loss, volume change and shift in snout position were measured through multi-temporal satellite data from 1989 to 2016 and kinematic GPS survey from 2015 to 2016 . The results obtained from satellite data indicate that in the last 27 years Chaturangi glacier snout has retreated $1172.57 \pm$ $38.3 \mathrm{~m}$ (average $=\mathbf{4 5 . 0 7} \pm \mathbf{4 . 3 1} \mathrm{m} /$ year) with a total area and volume loss of $0.626 \pm 0.001 \mathrm{sq} . \mathrm{km}$ and $0.139 \mathrm{~km}^{3}$ respectively. The field measurements through

*For correspondence. (e-mail: harishbisht890@gmail.com) 
differential global positioning system survey revealed that the annual retreating rate was $22.84 \pm 0.05 \mathrm{~m} /$ year. The large variations in results derived from both the methods are probably because of higher difference in their accuracy. Nevertheless, the results derived from both the methods are in agreement that Chaturangi glacier is retreating at a considerable rate.

Keywords: Glacier snout, kinematic survey, retreat rate, satellite data.

THE Himalayan region consists of a large number of glaciers. The regional hydrology and climatic variations in the Indian subcontinent are directly influenced by the Himalayan glaciers, which cover an area of about 33,000 sq. $\mathrm{km}$ (ref. 1). In the context of global warming and retreating rate, the Himalayan glaciers have always been a sensitive topic of discussion. Apart from climatic conditions, the dynamics of glaciers is also dependent on their characteristics and local aspects ${ }^{2}$. Change in snout position varies for different glaciers ${ }^{3}$; so it is important to monitor them regularly. The past terminus position of the glacier can be reconstructed from satellite imageries and terminal moraines ${ }^{4}$. To monitor the glacier length, area, snout position, volume and equilibrium line altitude (ELA), remote sensing technique can provide useful information ${ }^{5}$. Since the past few decades, remote sensingbased approach has been widely used for mapping glaciers utilizing various multi-temporal and multispectral data. This method allows monitoring of glaciers and has the ability to recognize the past retreating trends. The ground-based method is another technique for the estimation of glacial retreat. In this technique the geomorphological evidences and global positioning system (GPS) survey method are used to determine the retreating rate of a glacier ${ }^{4}$. Surveying glacier terminus using GPS is a straightforward and effective method to determine the actual retreating rate. The mapped terminus position by differential global positioning system (DGPS) over time provides a record of change in length, area and volume of the glacier ${ }^{6}$. Many tributary glaciers of the Gangotri glacier system are in withdrawing stage, while some are in disappearing stage. Several studies were conducted on the Gangotri glacier to estimate its recession by groundbased method $^{7,8}$ and satellite imageries ${ }^{9,10}$, while few studies were published about recession of its tributary glaciers ${ }^{11}$. To the best of our knowledge, there have been no attempts made earlier to measure the retreating rate of Chaturangi glacier, either by satellite data or groundbased methods. Only hydrochemical analysis of glacier melt water was carried out in the Chaturangi glacier region $^{12}$.

Therefore, the present study focuses on the Chaturangi glacier, which is one of the longest inactive tributary glaciers (not connected with the main trunk) of the Gangotri glacier system. This glacier has been selected for the present study because of its more dynamic nature and unknown recession rate. The main objective of this study is to reconstruct the snout position, temporal changes in areal extent and volume loss using multi-temporal satellite imagery and DGPS-derived data. Another objective is to compare the results obtained from both the methods, i.e. satellite-based monitoring and kinematic GPS-based study.

The Chaturangi glacier lies between $30^{\circ} 54^{\prime} 08^{\prime \prime}-$ $30^{\circ} 54^{\prime} 28^{\prime \prime} \mathrm{N}$ and $79^{\circ} 15^{\prime} 19^{\prime \prime}-79^{\circ} 6^{\prime} 18^{\prime \prime} \mathrm{E}$, in the Uttarkashi district, Uttarakhand, India (Figure 1$)^{7}$. The Chaturangi glacier consists of more than three active (connected with the trunk) tributary glaciers (Seeta, Suralaya, Vashuki, etc.) which form the Chaturangi glacier system ${ }^{7}$. It is an east-west-flowing, valley-type glacier; at present, it is $21.1 \mathrm{~km}$ long and occupies an area of about $43.83 \mathrm{sq} . \mathrm{km}$. The snout of the glacier is situated at an elevation of $4380 \mathrm{~m}$ amsl. It consists of about $20-25 \mathrm{~m}$ high ice wall and a glacier portal from where the Chaturangi river originates (Figure $2 a$ and $b$ ). The Chaturangi glacier was connected with the Gangotri glacier in 1971 (ref. 13), but now it has been detached and has lost its identity at the junction (Figure $2 c$ ). This is also evident from the satellite images of different years (Figure 3). These images show that the Chaturangi glacier was connected with Gangotri till 1989.

To obtain past position of Chaturangi glacier snout, retreating rate, total area and volume loss, multi-temporal satellite imageries (Landsat TM 1989, Landsat ETM + PAN 1999, IRS LISS III 2009 and Landsat Sentinel 2016) were downloaded (http://earthexplorer.usgs.gov/; http://bhuvan.nrsc.gov.in/), processed and geo-rectified using ERDAS imagine (ver. 14) and Arc GIS (ver. 10.2) software. Table 1 provides the comprehensive details of multi-temporal and multi-spectral satellite data acquired in cloudless condition (October and November). The registration error calculated while registering the images 1989 (Landsat TM), 1999 (Landsat ETM + PAN) and 2009 (LISS III) to base image 2016 (Landsat Sentinel) was 0.6 pixel or $6 \mathrm{~m}, 0.4$ pixel or $4 \mathrm{~m}$ and 0.5 pixel or $5 \mathrm{~m}$ respectively. In order to assess positional accuracy in results, the uncertainty was calculated using the formula ${ }^{14}$

$$
e=\sqrt{(a 1)^{2}+(a 2)^{2}}+E_{\mathrm{reg}}
$$

where $a 1$ is the spatial resolution of image $1, a 2$ the spatial resolution of image 2 (base image) and $E_{\text {reg }}$ is the image registration error.

Hence, the uncertainty for 1989 Landsat TM data can be estimated as follows

$$
e=\sqrt{(30)^{2}+(10)^{2}}+6=37.62 \mathrm{~m} .
$$

Similarly, the uncertainty was $22.03 \mathrm{~m}$ for Landsat $\mathrm{ETM}+\mathrm{PAN}$ and $30.54 \mathrm{~m}$ for LISS III. The temporal 

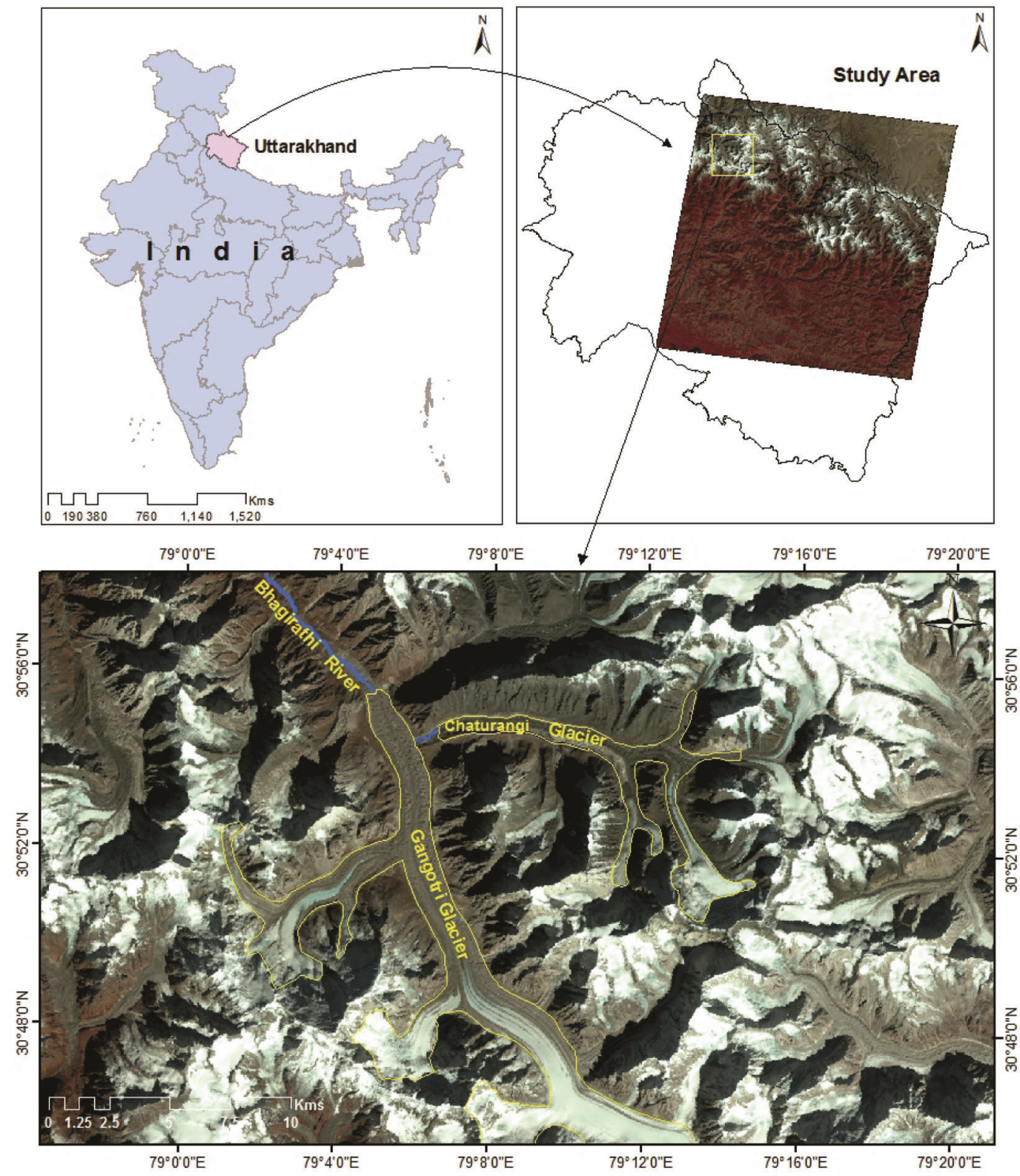

Figure 1. Location map of the study area with current position of Chaturangi glacier snout.

changes in areal extent of the glacier were measured with an accuracy of $\pm 0.002, \pm 0.0006, \pm 0.001$ and \pm 0.0002 sq. $\mathrm{km}$ for Landsat TM, Landsat ETM + PAN, LISS III and Sentinel images respectively, using the formula $^{14}$

$$
U_{\text {area }}=2 \mathrm{eV},
$$

where $U_{\text {area }}$ is the uncertainty in area, $e$ the terminus uncertainty and $V$ is the spatial resolution of the satellite image.

The volume of the glacier was calculated as a product of glacier area and thickness. The thickness of the glacier was measured using DGPS elevation difference at the top and bottom of the snout. The total loss of glacial volume is a sum of loss caused by border shrinking and fall in surface level ${ }^{15}$. The volume loss is calculated using hybrid $\operatorname{method}^{15}$, where area loss is measured through satellite imageries and surface lowering is measured through stake survey (Figure $2 d$ ). A total of 14 stakes were emplaced on the glacier surface up to $4 \mathrm{~km}$ upstream with the help of ice-drilling machine (Figure $2 e$ ), and the annual monitoring of these stakes through tape measure and DGPS. The annual retreating rate of the glacier snout was also delineated through kinematic GPS survey during 201516. In this method, a pair of Leica SR520 GPS receivers and AT502 antenna were used. One antenna was mounted on a solid bed rock located off the glacier 

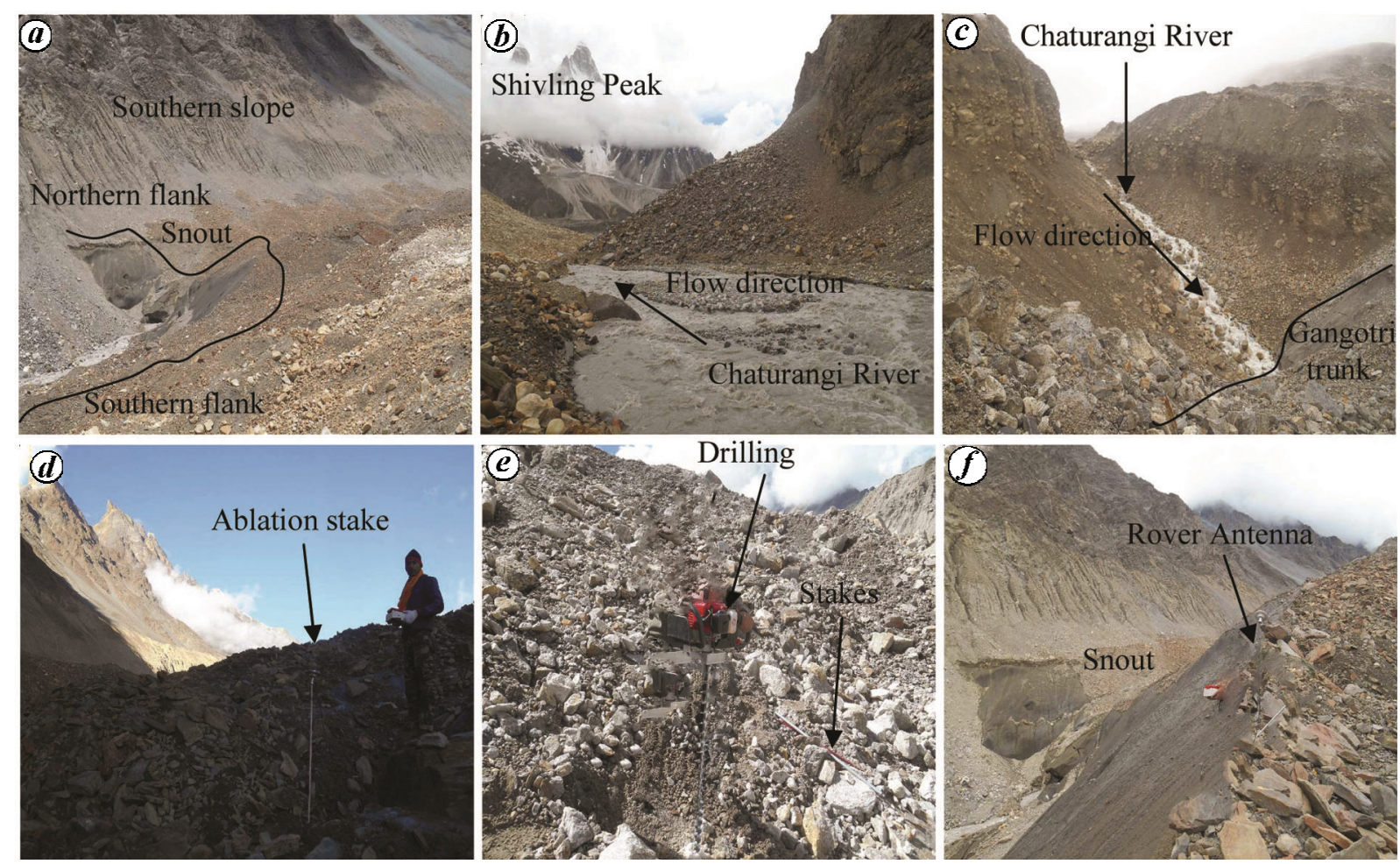

Figure 2. $\boldsymbol{a}$, Scenic frontal view of Chaturangi glacier with glacier portal and debris cover on its surface. $\boldsymbol{b}$, Photograph taken from Chaturangi glacier, river flowing towards Shivling peak. $c$, Chaturangi river meeting the main trunk glacier, snout of Chaturangi is far away from the Gangotri glacier. $\boldsymbol{d}$, Inserted ablation stake on the glacier surface to measure surface thinning. $\boldsymbol{e}$, Drilling on the glacier surface for inserting stakes. $\boldsymbol{f}$, Kinematic GPS survey along the snout of Chaturangi glacier.

Table 1. Details of multitemporal and multispectral satellite data from 1989 to 2016

\begin{tabular}{|c|c|c|c|}
\hline Satellite/sensor & Date of acquisition & Spatial resolution $(\mathrm{m})$ & Spectral resolution $(\mu \mathrm{m})$ \\
\hline Sentinel & 9 October 2016 & 10 & $\begin{array}{l}G=0.56 \\
R=0.66 \\
\text { NIR }=0.84\end{array}$ \\
\hline Liss III & 23 October 2009 & 23.5 & $\begin{array}{l}G=0.52-0.59 \\
R=0.62-0.68 \\
\text { NIR }=0.77-0.86\end{array}$ \\
\hline Landsat ETM + pan & 15 October 1999 & 15 & $\begin{array}{l}G=0.52-0.60 \\
R=0.63-0.69 \\
\mathrm{NIR}=0.76-0.90\end{array}$ \\
\hline Landsat TM & 15 November 1989 & 30 & $\begin{array}{l}G=0.52-0.60 \\
R=0.63-0.69 \\
\text { NIR }=0.76-0.90\end{array}$ \\
\hline
\end{tabular}

with one receiver and another as a rover with moving antenna. In the rover survey, terminus of the glacier was mapped by walking along the snout with the GPS receiver at the nearest possible track, $1-4 \mathrm{~m}$ distance from the glacier snout to avoid accidents from ice and debris fall (Figure $2 f$ ). This prefixed distance was considered during the processing of data. The generated raw data were processed using Leica SKI-PRO 3.0 software and position coordinates were presented in the form of WGS 84 coordinate system.

The results obtained from long-term satellite imageries and DGPS were used to determine the past position of snout, retreating trend and temporal changes in area of the glacier (Figures 3 and 4). The satellite-based remote sensing study suggests that the Chaturangi glacier has retreated $1172.57 \pm 38.3 \mathrm{~m}$ from 1989 to 2016 . Total retreat rate computed during three different periods, viz. 198999, 1999-2009 and 2009-16 was $482.98 \pm 43.59 \mathrm{~m}$, $269.96 \pm 37.66 \mathrm{~m}$ and $419.63 \pm 33.65 \mathrm{~m}$ respectively (Table 2). Reconstruction of the past snout position and cumulative retreating trend clearly showed that the retreating rate of the Chaturangi glacier was higher $(48.29 \pm$ $4.36 \mathrm{~m} /$ year) during the initial period, i.e. 1989-99, when it started detaching from the main trunk, lower 


\section{RESEARCH COMMUNICATIONS}
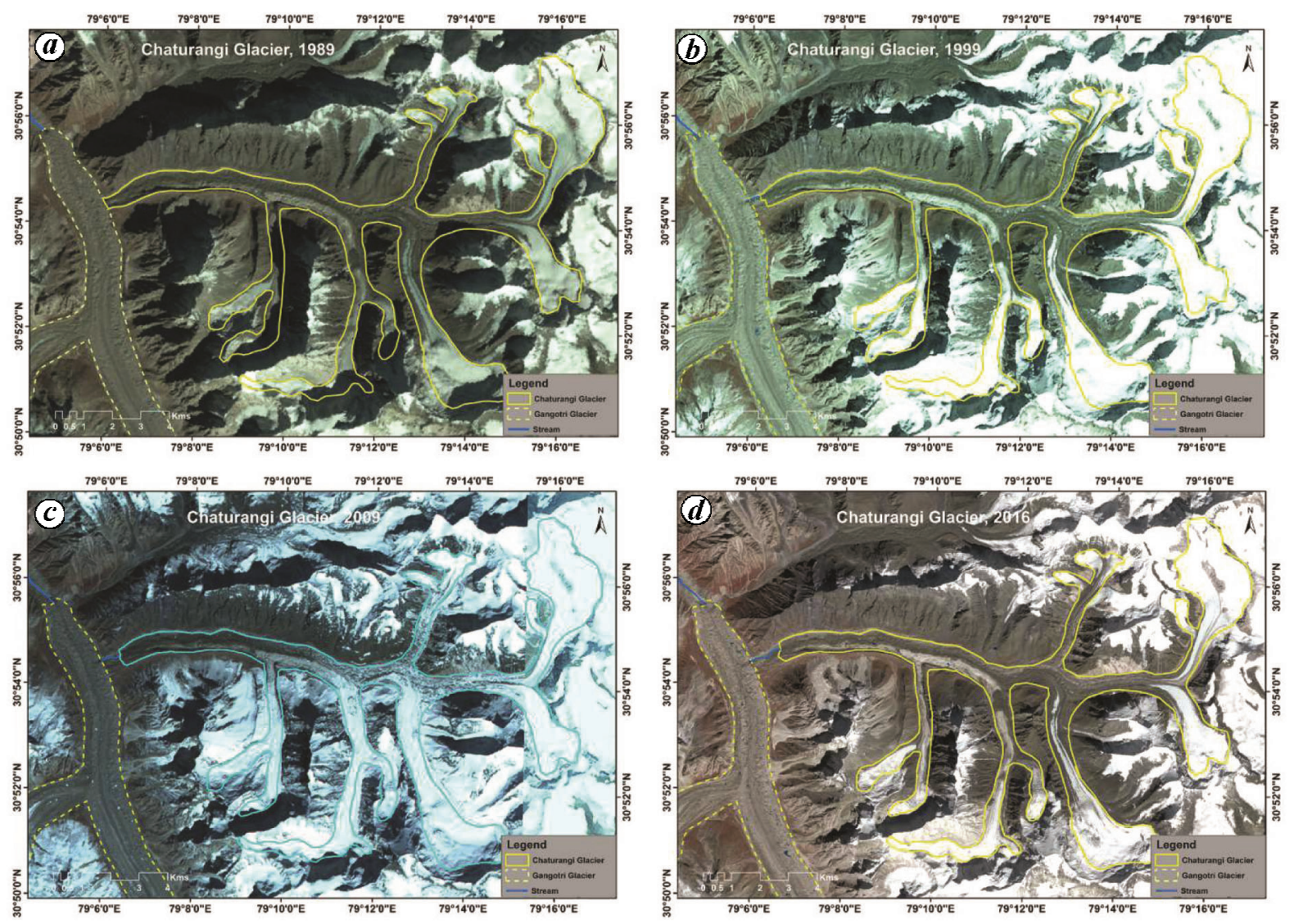

Figure 3. Satellite images of Chaturangi glacier with position of the snout in different years: $\boldsymbol{a}, 1989 ; \boldsymbol{b}, 1999 ; \boldsymbol{c}, 2009 ; \boldsymbol{d}, 2016$. (a) shows that till 1989 the Chaturangi glacier was connected with the Gangotri glacier.

Table 2. Recession rate, area and volume loss of Chaturangi glacier estimated using satellite data from 1989 to 2016

\begin{tabular}{|c|c|c|c|c|c|c|}
\hline $\begin{array}{l}\text { Time duration } \\
\text { (years) }\end{array}$ & $\begin{array}{l}\text { Total recession } \\
\text { (m) }\end{array}$ & $\begin{array}{l}\text { Retreating rate } \\
(\mathrm{m} / \text { year })\end{array}$ & $\begin{array}{c}\text { Area } \\
\text { (sq. km) }\end{array}$ & $\begin{array}{l}\text { Area loss } \\
(\text { sq. km) }\end{array}$ & $\begin{array}{l}\text { Volume } \\
\left(\mathrm{km}^{3}\right)\end{array}$ & $\begin{array}{l}\text { Volume loss } \\
\qquad\left(\mathrm{km}^{3}\right)\end{array}$ \\
\hline 1989 & & & $44.461 \pm 0.002$ & & 1.104 & \\
\hline 1989-19 & $482.98 \pm 43.59$ & $48.29 \pm 4.36$ & & -0.264 & & -0.052 \\
\hline 1999 & & & $44.197 \pm 0.0006$ & & 1.051 & \\
\hline 1999-2009 & $269.96 \pm 37.66$ & $26.99 \pm 3.77$ & & -0.158 & & -0.049 \\
\hline 2009 & & & $44.039 \pm 0.001$ & & 1.001 & \\
\hline 2009-16 & $419.63 \pm 33.65$ & $59.94 \pm 4.81$ & & -0.204 & & -0.036 \\
\hline 2016 & & & $43.835 \pm 0.0002$ & & 0.964 & \\
\hline Total & $1172.57 \pm 38.3$ & $45.07 \pm 4.31$ & & -0.626 & & -0.139 \\
\hline
\end{tabular}

(26.99 $\pm 3.77 \mathrm{~m} /$ year) during 1999-2009 and again higher (59.94 $\pm 4.81 \mathrm{~m} /$ year) during 2009-16 (Table 2). The area of the Chaturangi glacier during each observation year 1989, 1999, 2009 and 2016, was 44.461 \pm 0.002 , $44.461 \pm 0.002,44.461 \pm 0.002$ and $44.461 \pm 0.002$ sq. $\mathrm{km}$ respectively (Table 2 ). The area derived from the satellite data showed that the Chaturangi glacier exhibited loss up to $0.59 \%(-0.264 \mathrm{sq} . \mathrm{km}), 0.35 \%(-0.158 \mathrm{sq} . \mathrm{km})$ and $0.46 \%(-0.204$ sq. $\mathrm{km})$ during the observation period 1989-99, 1999-2009 and 2009-16 respectively (Table 2). The volume of the glacier was calculated for the period 1989-2016. The average thickness of the glacier in 2016 was $22 \mathrm{~m}$ and surface lowering was nearly the same in all the stakes with an average value of $10.5 \mathrm{~cm} /$ year. It has been assumed that the surface lowering will be the same throughout the glacier valley. The same surface lowering rate was also used to reconstruct the past volume because of unavailability of any other data. Even the best available DEM (USGS 3DEP, $1 \mathrm{~m}$ resolution) was not suitable for measuring surface lowering because of uncertainty. The result showed that the volume in 1989, 1999, 2009 and 2016 was $1.104,1.051,1.001$ and $0.964 \mathrm{~km}^{3}$ respectively. The calculated volume loss was $-0.052,-0.049$ and $-0.036 \mathrm{~km}^{3}$ for the period 1989-99, 1999-2009 and 


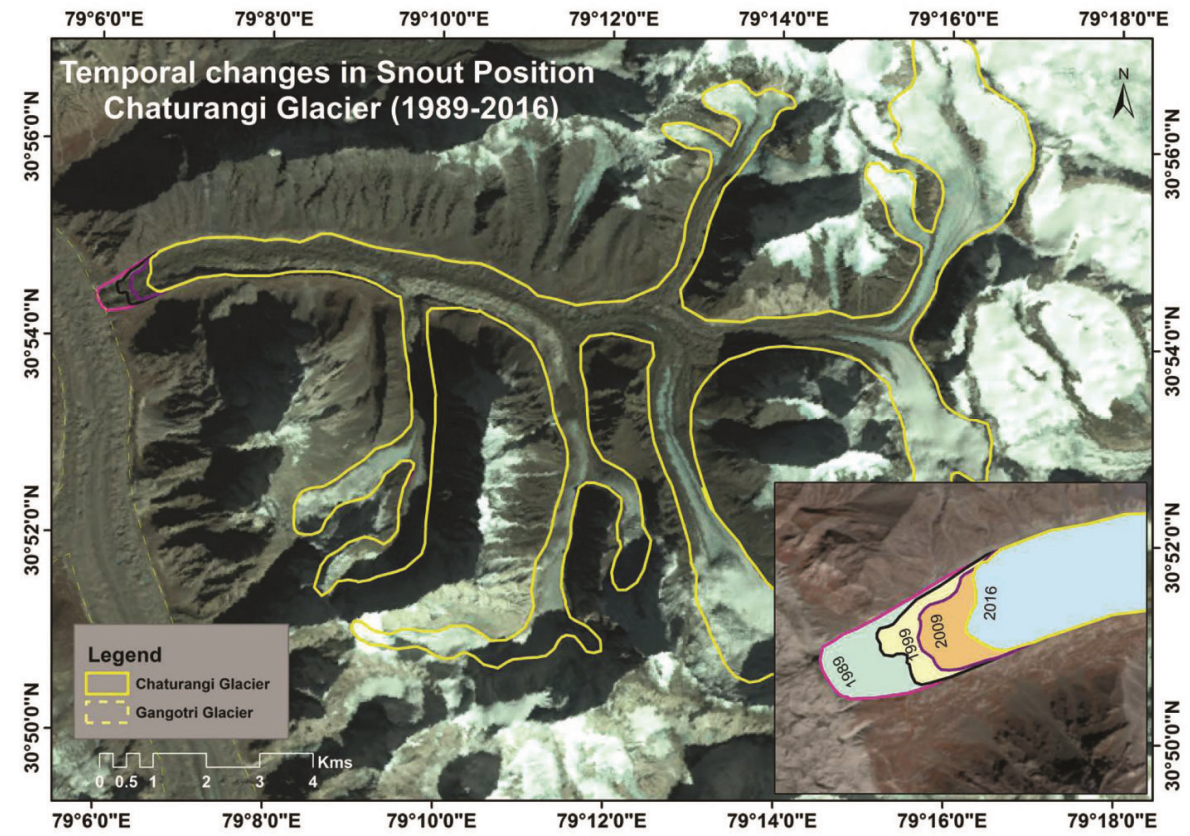

Figure 4. Temporal changes in the position of snout and glacier area, estimated using satellite imageries at 10 -year interval from 1989 to 2016.

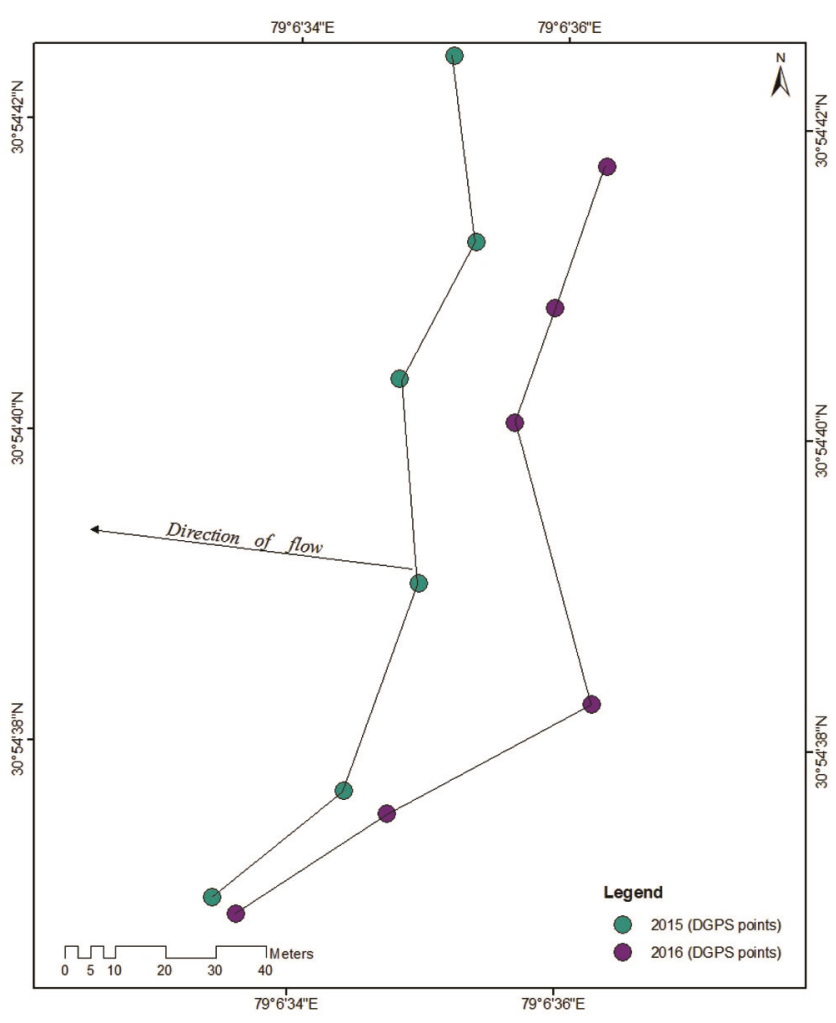

Figure 5. Retreat of Chaturangi glacier using kinematic GPS survey from 2015 to 2016.

2009-16 respectively (Table 2). These temporal fluctuations in retreating rate, area and volume loss of the glacier may be attributed to variation in climatic conditions, and behaviour of the summer and winter monsoons ${ }^{16,17}$. The average annual error in satellite-derived results varied from \pm 3.77 to $\pm 4.81 \mathrm{~m} /$ year for different sensors. The co-registration errors and low spatial resolution were the main cause of errors in the glacier mapping through satellite data ${ }^{18}$. In addition, some unavoidable factors like snowfields, debris cover and refreezing of water bodies also affected the accuracy ${ }^{19}$. The accuracy varied for different sensors, as sensors with spatial resolution $79 \mathrm{~m}$ (Landsat MSS), $30 \mathrm{~m}$ (Landsat TM), $5.8 \mathrm{~m}$ (LISS IV) and $2.5 \mathrm{~m}$ (Cartosat-1) showed uncertainty up to 40, 20, 15 and $10 \mathrm{~m}$ respectively ${ }^{20}$. The results derived from kinematic GPS survey during two consecutive years, viz. 2015 and 2016 showed that the average annual retreating rate of the glacier was around $22.84 \pm 0.05 \mathrm{~m} /$ year (Table 3 ), while it was $59.9 \pm 4.81 \mathrm{~m} /$ year for the same duration calculated from satellite data. The retreating rate of snout measured by satellite data was more than twice the GPSderived result, which is considered more accurate due to its higher precision. The retreating trend and shape of the snout constructed using DGPS points clearly reflect a higher recession of $43.59 \pm 0.05 \mathrm{~m}$ in the central part and lower recession of $4.88 \pm 0.04 \mathrm{~m}$ in the southern flank (Figure 5). A close examination of these results shows that the southern flank of the snout has retreated less than the northern flank $(36.34 \pm 0.07 \mathrm{~m})$. The southern flank of the glacier is retreating less probably because of the combination of three factors: (i) The glacial portal (ice cave from which the river originates) is present in the northern side of the snout, due to which subsidence of ice mass in the northern side is relatively higher than the southern side. (ii) Presence of debris on the surface of the glacier can significantly reduce its melting rate ${ }^{21}$. The southern flank of the Chaturangi glacier is thickly covered with debris than the other parts due to which there is 
Table 3. Position coordinates of differential global positioning system and resultant change in snout position of Chaturangi glacier during 2015 and 2016

\begin{tabular}{|c|c|c|c|c|c|c|}
\hline Year/points & $X$ (North) (m) & $Y$ (East) (m) & $\begin{array}{c}\text { Position } \\
\text { quality }(\mathrm{cm})\end{array}$ & $\begin{array}{l}\text { Change in } \\
N(\mathrm{~d} X)(\mathrm{m})\end{array}$ & $\begin{array}{l}\text { Change }(\mathrm{m}) \\
\text { in } E(\mathrm{~d} Y)\end{array}$ & $\begin{array}{c}\text { Resultant change in } \\
\text { position }\left(\mathrm{ma}^{-1}\right)\end{array}$ \\
\hline $2015-1$ & 1035527.85 & 5382152.28 & 4.03 & -4.75 & 1.11 & $4.88 \pm 0.04$ \\
\hline 2016-1 & 1035523.09 & 5382153.39 & 0.57 & & & \\
\hline $2015-2$ & 1035502.05 & 5382155.11 & 4.61 & -8.18 & 2.98 & $8.70 \pm 0.05$ \\
\hline $2016-2$ & 1035493.87 & 5382158.09 & 1.22 & & & \\
\hline $2015-3$ & 1035483.98 & 5382136.95 & 4.94 & -29.06 & 32.48 & $43.59 \pm 0.05$ \\
\hline $2015-4$ & 1035483.09 & 5382108.51 & 6.02 & -20.38 & 15.93 & $25.87 \pm 0.06$ \\
\hline $2016-4$ & 1035462.71 & 5382124.44 & 1.75 & & & \\
\hline $2015-5$ & 1035466.47 & 5382100.12 & 4.18 & -14.21 & 10.44 & $17.64 \pm 0.04$ \\
\hline $2016-5$ & 1035452.25 & 5382110.57 & 0.94 & & & \\
\hline $2015-6$ & 1035466.03 & 5382071.40 & 6.86 & -26.552 & 24.816 & $36.34 \pm 0.07$ \\
\hline $2016-6$ & 1035439.48 & 5382096.21 & 0.49 & & & \\
\hline Mean & & & & -17.19 & 14.63 & $22.84 \pm 0.05$ \\
\hline
\end{tabular}

a lower melting in the southern portion of the snout. (iii) The solar insolation can enhance or reduce melting of ice. The Chaturangi glacier valley stretches in the EW direction, bounded by mountains in the northern and southern sides. This type of valley geometry can control the amount of solar radiation falling in the valley. In the Himalaya, the southern slope of the mountain receives higher solar insolation than the northern slope ${ }^{22}$. In case of the Chaturangi glacier, the northern flank of the snout joins the southern slope and the southern flank joins the northern slope due to which there is less melting in the southern flank. A similar pattern of retreat has also been reported from a previous study on the Gangotri glacier ${ }^{8}$. A major loss of glaciated areas was also reported from the northern slope of Garhwal Himalayas ${ }^{23}$ driven by solar insolation ${ }^{24}$. The variability in retreating rate is not only controlled by climate change but is also governed by glacier size, type, topographic setting ${ }^{19}$ and debris cover. The retreating rate of the Chaturangi glacier (22.84 \pm $0.05 \mathrm{~m} /$ year) is higher than the Gangotri glacier (12.10 \pm $0.04 \mathrm{~m} /$ year) ${ }^{8}$ because of its smaller size (smaller relative to the Gangotri glacier) and fast response time to climatic variability $^{25}$. A GIS-based study, supported by remote sensing data and DGPS survey was used to determine temporal changes in areal extent of glacier and shift in the snot position. Both methods have their own advantages and disadvantages. For example, in situ measurements of glaciers year after year using DGPS are logistically difficult and costly, but provide precise retreating rate. Whereas satellite data provide a bird's eye view of the whole glacial body, from which we can easily calculate the area and delineate the glacial catchment boundaries. The shortcoming of this approach is its uncertainty; even the Cartosat, $2.5 \mathrm{~m}$ resolution has an uncertainty of $10 \mathrm{~m}$ (ref. 20). Another constraint of using satellite data is separation between stagnant glacier ice and active debriscovered ice, which is challenging during glacier terminus mapping ${ }^{20}$. The presence of ice blocks in front of the snout after its disintegration sometimes creates a problem in identifying the actual snout position through satellite. The present study concludes that remote sensing method is suitable for large area and long-term study, while kinematic GPS is more appropriate for the annual monitoring of retreating rate of individual glacier snout. Both the studies performed individually are not sufficient to compute the actual retreating rate; however, a combination of both can provide significant insights into such studies with better interpretation of the results. Therefore, the choice of using both the approaches depends upon the objective of the study. The present study also emphasizes on mapping of all the tributary glaciers in order to assess the overall changes in the main glacier system and its health.

1. Dyurgerov, M. B. and Meier, M. F., Mass balance of mountain and sub-polar glaciers: a new global assessment for 1961-1990. Arct. Alp. Res., 1997, 29(4), 379-391.

2. Singh, D. S., Tangri, A. K., Kumar, D., Dubey, C. A. and Bali, R., Pattern of retreat and related morphological zones of Gangotri glacier, Garhwal Himalaya India. Quat. Int., 2016, 1-10.

3. Dhobhal, D. P., Gergan, J. T. and Thayyen, R. J., Recession and morphogeometrical changes of Dokriani glacier (1962-1995) Garhwal Himalaya, India. Curr. Sci., 2004, 86(5), 692-696.

4. Kaser, G., Fountain, A. and Jansson, P., A manual for monitoring the mass balance of mountain glacier. IHP-VI Technical Documents in Hydrology, UNESCO, Paris, 2003, p. 107.

5. Negi, H. S., Thakur, N. K., Ganju, A. and Snehmani, Monitoring of Gangotri glacier using remote sensing and ground observations. J. Earth Syst. Sci., 2012, 121(4), 855-866.

6. Karpilo, R. D., Glacier monitoring techniques. In Geological Monitoring: Boulder (eds Young, R. and Norby, L.), Geological Society of America, Colorado, USA, 2009, pp. 141-162.

7. Naithani, A. K., Nainwal, H. C., Sati, K. K. and Prasad, C. P., Geomorphological evidences of retreat of Gangotri glacier and its characteristics. Curr. Sci., 2001, 80, 87-94.

8. Kumar, K., Dumka, R. K., Miral, M. S., Satyal, G. S. and Pant, M., Estimation of retreat rate of Gangotri glacier using rapid static and kinematic GPS survey. Curr. Sci., 2008, 94(2), 258-262.

9. Tangri, A. K., Chandra, R. and Yadav, S. K. S., Temporal monitoring of the snout, equilibrium line and ablation zone of Gangotri glacier through remote sensing and GIS techniques - an attempt at deciphering the climatic variability. Geol. Surv. India (Spec. Publ.), 2004, 80, 145-153. 
10. Bhambri, R., Bolch, T. and Chaujar, R. K., Frontal recession of Gangotri glacier, Garhwal Himalayas, from 1965 to 2006, measured through high-resolution remote sensing data. Curr. Sci., 2011, 102(3), 489-494.

11. Srivastava, D., Recession of Gangotri glacier, Geol. Surv. India, Spec. Publ., 2004, 80, 21-32.

12. Singh, V. B., Ramanathan, A., Pottakkal, J. G. and Kumar, M., Hydrochemistry of meltwater of the Chaturangi glacier, Garhwal Himalaya, India. Proc. Natl. Acad. Sci., India, 2015, 85(1), 187195.

13. Vohra, C. P., Gangotri glacier, Indian Mountaineer, Indian Mountaineering Foundation, 1988, pp. 51-58.

14. Hall, D. K., Bahr, K. J., Shoener, W., Bindschadler, R. A. and Chien, J. Y. L., Consideration of the errors inherent in mapping historical glacier positions in Austria from the ground and space. Remote Sensing Environ., 2003, 86, 566-577.

15. Thompson, L. G., Brecher, H. H., Thompson, E. M., Hardy, D. R. and Mark, B. G., Glacier loss on Kilimanjaro continues unabated. Proc. Natl. Acad. Sci., USA, 2009, 106(47), 19770-19775.

16. Thayyen, R. J. and Gergan, J. T., Role of glaciers in watershed hydrology: a preliminary study of a Himalayan catchment. Cryosphere, 2010, 4, 115-128.

17. Dumka, R. K., Kotlia, B. S., Miral, M. S., Joshi, L. M., Kumar, K. and Sharma, A. K., First GPS derived recession rate in Milam glacier, higher central Himalaya, India. Int. J. Eng. Sci., 2013, 2, $58-63$.

18. Shangguan, D., Liu, S., Ding, Y., Ding, L., Xu, J. and Li, J., Glacier changes during the last forty years in the Tarim Interior River basin, northwest China. Proc. Natl. Acad. Sci., India, 2009, 19, 727-732.

19. Pan, B. T. et al., Glacier changes from 1966-2009 in the Gongga Mountains, on the south-eastern margin of the Qinghai-Tibetan Plateau and their climatic forcing. Cryosphere, 2012, 6, 1087 1101

20. Bhambri, R., Bolch, T., Chaujar, R. K. and Kulshreshta, S. C., Glacier changes in the Garhwal Himalayas, India 1968-2006 based on remote sensing. J. Glaciol., 2011, 57(203), 543-556.

21. Pratap, B., Dobhal, D. P., Mehta, M. and Bhambri, R., Influence of debris cover and altitude on glacier surface melting: a case study of Dokriani Glacier, central Himalaya, India. Ann. Glaciol., 2015, 56(70), 9-15.

22. Ahmad, N. and Rais, S., Himalayan Glaciers, APH Publishing Corporation, New Delhi, 1999

23. Pandey, A. C., Ghosh, S. and Nathawat, M. S., Evaluating patterns of temporal glacier changes in Greater Himalayan Range, Jammu and Kashmir, India. Geocarto Int., 2011, 26(4), 321-338.

24. Aizen, V., Aizen, E. and Nikitin, S., Glacier regime on the northern slope of the Himalaya (Xixibangma glaciers). Quaternary Int., 2002, 27-39.

25. Kulkarni, A. V., Bahuguna, I. M., Rathore, B. P., Singh, S. K., Randhawa, S. S., Sood, R. K. and Dhar, S., Glacial retreat in Himalaya using Indian Remote Sensing satellite data. Curr. Sci., 2007, 92(1), 69-74.

ACKNOWLEDGEMENTS. We thank the Department of Science and Technology, New Delhi for financial support and the Director, G.B. Pant National Institute of Himalayan Environment and Sustainable Development, Kosi-Katarmal, Almora for providing us the necessary working facilities. We also thank Naveen Joshi, Nikesh Pandey, Jagdish Pandey, Pankaj Kandpal and Mohit Tewari for assistance in the field and laboratory.

Received 21 May 2017; revised accepted 30 October 2018

\section{Analysis of iron ore, iron slag and soils of termite nest from Wui village, Nagaland, India}

\author{
Tiatemjen Tzudir ${ }^{1}$, Tiatoshi Jamir ${ }^{1, *}$ and \\ Sukanya Sharma ${ }^{2}$
}

${ }^{1}$ Department of History and Archaeology, Nagaland University, Kohima Campus, Meriema, Kohima 797 001, India

${ }^{2}$ Department of Humanities and Social Sciences,

Indian Institute of Technology, Guwahati 781 039, India

\begin{abstract}
Analysis of iron slag, iron ore and soils of termite nest traditionally utilized in iron forging was conducted in Wui village, Nagaland, India using various techniques. The present study helps in understanding and identifying various chemical properties/compositions, mineralogical qualities and quantities of iron content along with other oxides from the region.
\end{abstract}

Keywords: Iron ore, haematite, metallographic analysis, slag, termite nest.

EARLY metallurgy is known to have been an intellectual and social activity, wherein technology is the product of complex ideology and careful social negotiations ${ }^{1}$. The significance of iron socially has been demonstrated on a global level. Possibly the earliest use of iron was in the form of ochre pigment. Colourful iron oxides of yellow, red and brown shades have been used throughout history as pigments in art and decorations ${ }^{2}$. According to Schweitzer ${ }^{3}$, metals have been widely used for thousands of years, commencing from the Bronze Age to the Iron Age. The timeline of human civilization is represented on the basis of processing technology and the classification of traditional metals into ferrous and non-ferrous ${ }^{4}$. Archeologically, bronze and iron objects are considered as the most important materials that bear crucial information on the technological and socio-political environments of a past community, a notion previously confirmed by C. J. Thomsen in 1831 through his classification of archaeological objects and further categorization of human societies into Stone, Bronze and Iron Ages $^{5}$. Metal production involves a series of engineering processes vis-à-vis smelting of raw materials from ores, making of alloys and various other thermo-mechanical treatments applied in fabrication in understanding the formation of structures that could be traced only through strict scientific methodologies ${ }^{6}$. The present study helps us understand and identify various chemical properties/ compositions, mineralogical qualities and quantities of iron content along with other oxides that might provide crucial data on early iron technology.

*For correspondence. (e-mail: tiatoshijamir@rediffmail.com) 